\title{
KONZUMÁCIA MÄSA NA HRADOCH V NOVOVEKU: PRÍPADOVÁ ŠTÚDIA Z HRADU DOBRÁ NIVA
}

\author{
KATARÍNA ŠIMUNKOVÁ - NOÉMI BELJAK PAŽINOVÁ
}

\begin{abstract}
Abstrakt: Ciel'om príspevku je predstavit' a interpretovat' faunálne pozostatky z archeologického výskumu predhradia NKP Hrad Dobrá Niva v katastrálnom území obce Podzámčok, okres Zvolen. Analýzou osteologického materiálu bola zistená vel'ká rozmanitost' druhov zvierat s dominanciou domácich druhov nad lovenými. Archeologická vzorka fauny poukazuje hlavne na bežný domáci odpad, čo dokladajú viaceré stopy po sekaní a rezaní na kostiach. Na niektorých fragmentoch boli tiež zachytené stopy po zuboch hlodavcov. Na kostiach domácich druhov (hovädzi dobytok, ovca/koza, ošípaná) boli spozorované aj známky po tepelnom spracovani. Vzhl'adom na prírodné prostredie, v ktorom je hrad Dobrá Niva zasadený, analýza osteologického materiálu zvierat poukázala na lokálnu ekonomiku obyvatelov hradu pri ziskavaní mäsitej potravy s využitím lovu v okolitých lesoch, vodách a na pasienkoch ako doplnkovej stravy.
\end{abstract}

Kl'účové slová: hrad Dobrá Niva - archeologický výskum - predhradie - archeozoológia - lokálna ekonomika-15.-17. storočie.

\section{The Consumption of Meat in Castles in the Modern Age: A case study from the Dobrá Niva castle}

Abstract: This contribution presents and interprets the relics of fauna yielded by archaeological research into the outer bailey of the Dobrá Niva castle, a national cultural monument, in the cadastral zone of the village of Podzámčok, the Zvolen district. The analysis of osteological material showed a variety of animal species, with domestic animals prevailing over those hunted. The archaeological sample of fauna points towards relatively common household waste, which is confirmed by multiple traces of chopping and carving on the bones. Some bone fragments contained traces of rodents' teeth. The bones of domestic animals (cattle, sheep/goat, pig) also featured traces of cooking. In regard to the natural environment in which the Dobrá Niva castle is located, the analysis of the osteological material bears witness of the local economy of the castle residents in the provision of meat, supplemented with hunting in the surrounding woods and on pastures and fishing.

Key words: Dobrá Niva castle - archaeological research - bailey - archaeozoology - local economy 15th-17th centuries.

NKP Hrad Dobrá Niva je situovaný na homol’ovitej vyvýšenine (obr. 1) vo vzdialenosti $3 \mathrm{~km}$ severne od eponymnej obce na strednom Slovensku v okrese Zvolen. Ruina patrí do katastra obce Podzámčok, ktorá sa vyvinula z majera pod hradom. Ako národná kultúrna pamiatka je hrad evidovaný od roku 1963 (číslo v Ústrednom zozname pamiatkového fondu je 1110/1).

Hradný areál má dvojdielnu dispozíciu oválneho pôdorysu s rozmermi ca $80 \times 90 \mathrm{~m}$ (obr. 2). $\mathrm{Na}$ vrchole návršia bolo malé hradné jadro, dosahujúce vonkajšie rozmery približne $25 \times 20 \mathrm{~m}$. $\mathrm{Z}$ jeho architektúr sa nad terénom zachovala len čast' vonkajšej obvodovej steny paláca s pozostatkami arkiera a okenných otvoroch troch podlaží. Hradné jadro koncentricky obklopovalo predhradie.

Hrad sa prvýkrát spomína v listinách už v roku 1308, ked’ vojsko nastupujúceho uhorského král'a Karola Róberta vydobylo Dobronivský hrad spolu s d’alšími pevnost'ami od zvolenského župana Demetera. O zdržiavaní sa král'ov na Dobronivskom hrade svedčia král'ovské listiny vydané ,in Dobronya“ v roku 1377 Ludovítom I. a v roku 1404 král'om Žigmundom (Maliniak 2014, 54). Z obdobia vrcholného stredoveku sa však na predhradí zachovalo len menšie množstvo artefaktov. Zastúpený tu bol hlavne renesančný materiál spätý s novovekými dejinami hradu, ktoré sú po striedaní sa majitel'ov v 15. a 16. storočí od 17. storočia spojené s rodinou Esterházi. V roku 1638 dostal zvolenské a dobronivské panstvo do vlastníctva barón Pavol Esterházi (1587-1645) a až do roku 1710 sú postupne ako vlastníci uvádzaní jeho synovia a dcéry. Podla majetkových súpisov Dobronivského panstva z roku 1710 je zámok už opustený a spôsobuje len výdavky (Maliniak 2014a, 63). 


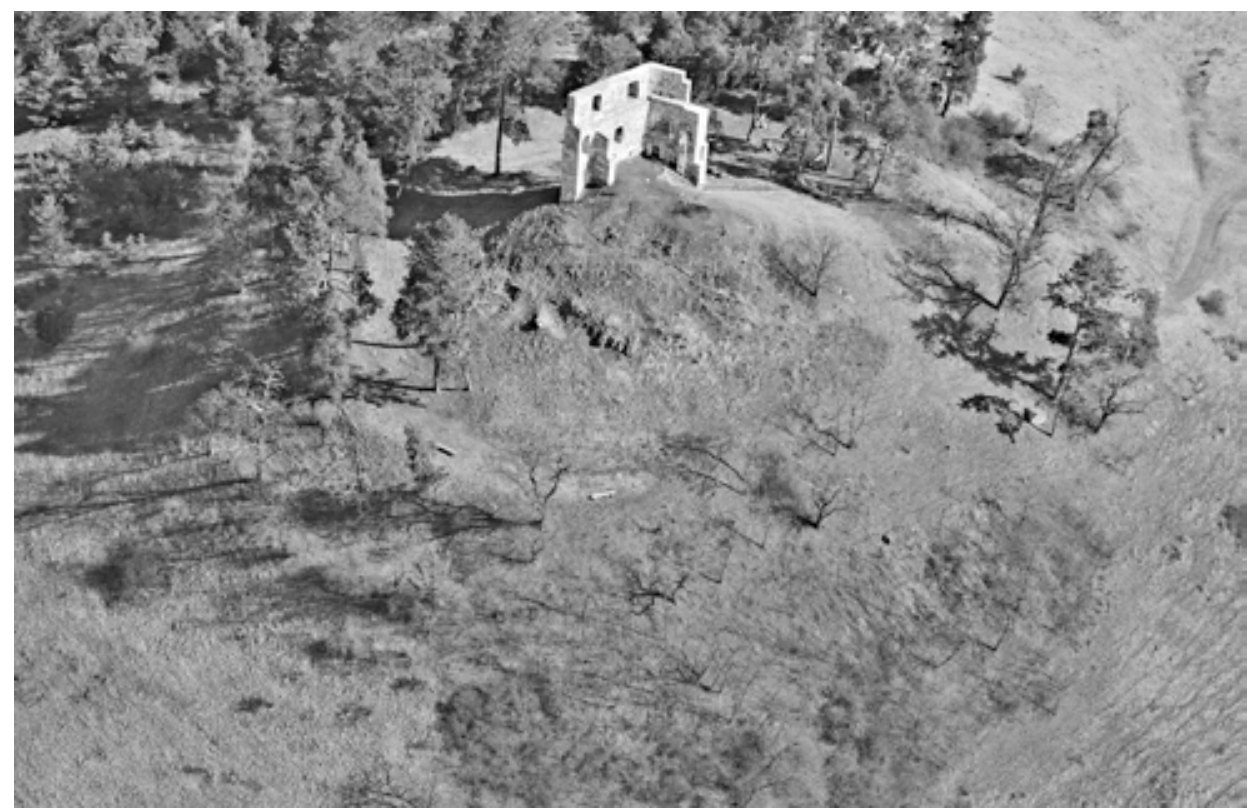

Obr. 1. Hrad Dobrá Niva, predhradie. Letecká snímka hradného kopca. Foto J. Beljak. Abb. 1. Burg Döbring, Vorburg. Luftaufnahme des Burghügels. Foto J. Beljak.

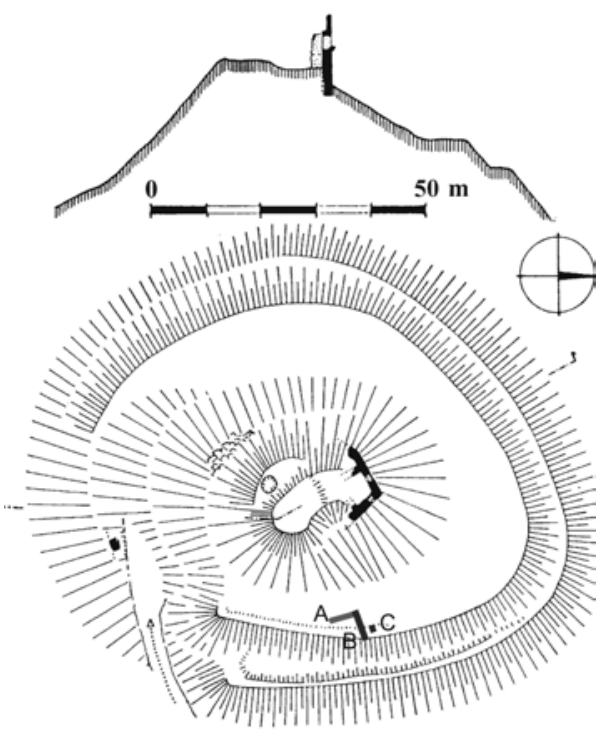

Obr. 2. Hrad Dobrá Niva, predhradie. Pôdorys a profil hradného návršia podl’a M. Šimkovica (čierna farba) a realizované archeologické sondy na predhradí $\mathrm{A}$ - sonda 2/2013, B - sonda 1/2014, C - sonda 1A/2014.

Abb. 2. Burg Döbring, Vorburg. Grundriss und Profil der Burganhöhe nach M. Šimkovic (schwarze Farbe) und in der Vorburg gelegte archäologische Sondierschnitte A - Sondierschnitt 2/2013, B - Sondierschnitt 1/2014, C - Sondierschnitt 1A/2014.
Archeologický výskum na lokalite uskutočnila Katedra archeológie UKF v Nitre v rokoch 2013 (v tejto sezóne v spolupráci s Archeologickým ústavom SAV v Nitre) a 2014. Výskum priniesol nové informácie o datovaní hradu z hl'adiska materiálnej kultúry i nové poznatky o stavebno-konštrukčnom vývoji hradného areálu. Terénne práce pomohli k spresneniu pôdorysu hradného paláca a poznaniu doteraz neznámych prestavieb. Zároveň sa podarilo doplnit' aj údaje o chronológii osídlenia a existencii drevenej palisády v blízkosti terénnej hrany vo východnej časti predhradia (Beljak Pažinová-Beljak-Šimkovic 2015).

Napriek malému rozsahu výskumu na predhradí $\left(13,5 \mathrm{~m}^{2}\right)$ bol objavený rozsiahly nálezový súbor fragmentov keramiky, kachlíc, téglikov, kovových predmetov a pod., vrátane početného zvieracieho osteologického materiálu, ktorý sa podarilo komplexne spracovat'. Ciel'om príspevku je prezentovat' analýzu súboru zvieracích kostí a na základe zistených výsledkov poukázat' na ekonomiku jeho obyvatel'ov.

Všetky kosti pochádzajú z troch sond $(2 / 2013,1 / 2014,1 \mathrm{~A} / 2014)$ situovaných vo 
východnej časti predhradia, pričom analyzované boli tie zvieracie kosti a ich fragmenty, ktoré pochádzali z vrstiev s keramikou a kachlicami datovanými do neskorého stredoveku a včasného novoveku (15.-17. storočie). Hoci ide o pomerne vel'ký časový rozsah, osteologický materiál nebolo možné bližšie časovo rozdelit'.

\section{Metodológia spracovania archeozoologického materiálu}

Anatomické a taxonomické určenie kostí bolo urobené na základe dostupných publikácií veterinárnych lekárov, anatómov, archeozoológov (Adams-Crabtree 2008; France 2009, Kolda 1951; Popesko 2007; Schmidt 1972) a zároveň pomocou vlastnej porovnávacej zbierky.

Skupina malých prežúvavcov označených ako Ovis/Capra zahŕňa oba druhy podčelade Caprinae - ovcu a kozu domácu. Pokial' bolo možné, diferenciácia ich kostí bola uskutočnená podla článkov J. Boessneckovej (1969), B. J. Adamsa a P. J. Crabtree (2008), P. Haelsteada a P. Collinsovej (1995; 2002), S. Paynea (1973).

Každá kost', ktorá bola zmeratel'ná (príp. nejaké časti z nej), sa zmerala digitálnym posuvným meradlom, pričom metodika meraní bola prevzatá od A. van den Driesch (1976). Podl'a nameraných hodnôt boli následne prepočítané kohútikové výšky zvierat (napr. Driesch-Boessneck 1974; Teichert 1969). Na určenie približného veku zvierat boli použité metódy podla epifýzového zrastenia (Reitz-Wing 2008, 72) a erupcie zubov a ich obrusu (Grant 1982; Payne 1973).

V analýze boli, samozrejme, zahrnuté aj kvantifikačné metódy, a to konkrétne NISP a MNI (Klein-Cruz-Uribe 1984, 25; Kyselý 2004, 282-284; Reitz-Wing 2008, 202-204). Doplnkovou metódou bola hmotnost' fragmentov, pričom kosti boli vážené na vedeckých váhach zn. Kern, s presnostou na dve desatiny gramu.

Kvantifikačná metóda NISP (počet identifikovaných fragmentov/kostí) bola počítaná pre jednotlivé kosti/fragmenty, hoci fragmenty boli zároveň zlepené a jasne radené k jednej kosti (napríklad nezrastené epifýzy, určite patriace k danej diafýze), označené ako jedna kost'/fragment na použitie výpočtu MNI. Pri čel'ustiach bola za jednotku považovaná dolná alebo horná čel'ust' so zubami, ktoré v nej boli zakotvené.

Hodnoty MNI (minimálny počet jedincov) boli vypočítané na základe početnosti anatomického prvku a jeho častí s prihliadnutím na určenie strany, v kombinácii s fragmentárnostou a s vekovým určením jednotlivých druhov.

\section{Charakteristika archeozoologického materiálu}

Analyzovaný archeozoologický materiál tvorilo dohromady 1660 fragmentov kostí s hmotnost'ou približne 14,8 kg. Do skupín neurčitel'ných druhov (Indet.), resp. do skupiny vel'ký, stredný a malý cicavec, bolo zaradených 907 kusov (54,6\%) s hmotnost'ou 2 979,5 g (20\%).

Analýzou osteologického materiálu bola zistená vel'ká rozmanitost' druhov zvierat. V súbore dominovali domáce druhy: hovädzí dobytok (Bos primigenius f. taurus), ošípaná (Sus scrofa f. dom.), koza (Capra aegagrus f. hircus), ovca (Ovis aries $f$. aries), kôň (Equus ferus $f$. caballus), skupina ovca /koza (Ovis/Capra), s malým podielom hydiny - kury domácej (Gallus gallus f. dom.) a husi domácej (Anser anser f. dom.). Domáce druhy tvorili celkovo 41,7\% (693 ks) $\mathrm{z}$ identifikovaných fragmentov (tab. 1).

Zo zastúpených druhov domácich zvierat v metóde NISP,t. j. v počte identifikovaných fragmentov/kostí, prevažoval hovädzí dobytok. Na druhom mieste bola kategória ovca/koza (vrátane rozlíšených druhov kozy a ovce) a na tret'om ošípaná. Hmotnostne prevažoval rovnako hovädzí dobytok $(65,4 \%$ z celkovej hmotnosti identifikovaných domácich druhov), nasledovala ošípaná (18\%) a ovca/koza (14,9\%).

Pokial' ide o MNI, teda o minimálny počet jedincov, hovädzí dobytok, ako aj kategória ovce/kozy (vrátane rozlíšených druhov ovce a kozy) boli zastúpené minimálne štyrmi jedincami, ošípaná tromi jedincami a kôn̆, rovnako ako aj druhy hydiny boli po jednom jedincovi. 


\begin{tabular}{|c|c|c|c|c|c|c|}
\hline & Druh & Druh (latinský názov) & NISP & NISP (\%) & Hmotnost' (g) & MNI \\
\hline \multirow{6}{*}{ 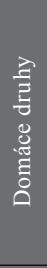 } & Hovädzí dobytok & Bos prim. f.taurus & 240 & 14,5 & 7172,1 & 4 \\
\hline & Kôň & Equus ferus f. caballus & 2 & 0,1 & 161,72 & 1 \\
\hline & Ovca/koza & Ovis/Capra & 228 & 13,7 & 1637,22 & 4 \\
\hline & Ošípaná & Sus scrofa f. dom. & 204 & 12,3 & 1972,87 & 3 \\
\hline & Kura domáca & Gallus gallus f. dom. & 11 & 0,7 & 13,72 & 1 \\
\hline & Hus domáca & Anser anser f. dom. & 8 & 0,5 & 8,61 & 1 \\
\hline \multirow{9}{*}{ 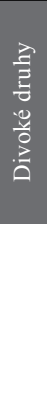 } & Jeleň európsky & Cervus elaphus & 18 & 1,1 & 806,46 & 1 \\
\hline & Zajac pol'ný & Lepus europaeus & 20 & 1,2 & 39,25 & 1 \\
\hline & Hlodavec & Rodentia sp. & 1 & 0,1 & 0,06 & 1 \\
\hline & Vtáky & Aves sp. & 19 & 1,1 & 13 & 3 \\
\hline & Ryby & Pisces sp. & 2 & 0,1 & 1,67 & 1 \\
\hline & Neidentifikované & & 212 & 12,8 & 557,65 & \\
\hline & malý cicavec & & 26 & 1,6 & 60,25 & \\
\hline & stredný cicavec & & 601 & 36,2 & 1513,18 & \\
\hline & vel'ký cicavec & & 68 & 4,1 & 848,42 & \\
\hline
\end{tabular}

Tabela 1. Hrad Dobrá Niva, predhradie. Kvantifikačná tabul'ka zvieracích druhov. Tabelle 1. Burg Döbring, Vorburg. Quantifizierungstabelle der Tierarten.

U hovädzieho dobytka bolo možné určit' vek len pri jednom jedincovi, a ten bol podl'a obrusu zubov starý menej ako 6 mesiacov. U kategórie koza/ovca bolo možné určit' vek u štyroch jedincov. Jeden mal 2-6 mesiacov, druhý 6-16 mesiacov a tretí 24-84 mesiacov. U týchto druhov nebolo možné vypočítat' kohútikovú výšku kvôli fragmentácii kostí. U ošípanej bol zistený vek aj výška. Jedno zviera bolo porazené vo veku 16 mesiacov a d’alšie malo okolo 24 mesiacov. Kohútiková výška u troch určených jedincov bola $68,95 \mathrm{~cm}, 70,16 \mathrm{~cm}$ a $70,62 \mathrm{~cm}$.

Z divých druhov (graf 2) boli vo vzorke reprezentované nasledovné druhy: jeleň obyčajný (Cervus elaphus) a zajac pol'ný (Lepus europaeus). Prítomné boli aj divé druhy vtákov (Aves sp. indet.), ryby (Pisces sp. indet.) a identifikovaná bola aj jedna kost' z bližšie neurčeného hlodavca. Bližšia identifikácia vtákov a rýb nebola možná pre absenciu relevantnej porovnávacej zbierky. Okrem vtákov zastúpených tromi jedincami boli vymenované druhy a skupiny reprezentované po jednom jedincovi.

\section{Stopy po zásahoch na kostiach a účel využitia zvierat}

Na základe zistených stôp po zásahoch na kostiach sa vieme vyjadrit' aj k využitiu zvierat. Umelé zásahy poukazujú na rezanie, sekanie (obr. 3), dokonca i pílenie kostí, čo naznačuje využitie hlavne pre kuchynské účely. V súbore z predhradia hradu Dobrá Niva boli tieto stopy zachytené na 64 (3,8\%) fragmentoch (graf 3).

Stopy po sekaní malo 44 fragmentov: na dlhých kostiach (17ks), lopatkách (11ks), na rebrách, stavcoch, ale aj na dolnej čel'usti a panve, a to predovšetkým na kostiach hovädzieho dobytka, ovce/kozy, ošípanej, ale aj jeleňa. Z toho vyplýva, že šlo pravdepodobne o porciovanie kostí väčších zvierat pre kuchynské účely.

Ďalšia kategória umelých zásahov spozorovaných na kostiach bolo rezanie. Stopy po tejto aktivite boli zaznamenané na 14 fragmentoch (metapódiá, dolná čel'ust', vretenná kost', rebrá, lopatky), pochádzajúcich z hovädzieho dobytka, ošípanej a ovce/kozy.

Znaky pílenia boli spozorované na štyroch fragmentoch. Pravdepodobne ide o prípravu polotovaru na d’alšie spracovanie. Pochádzali z metapódií hovädzieho dobytka a kozy/ovce, 


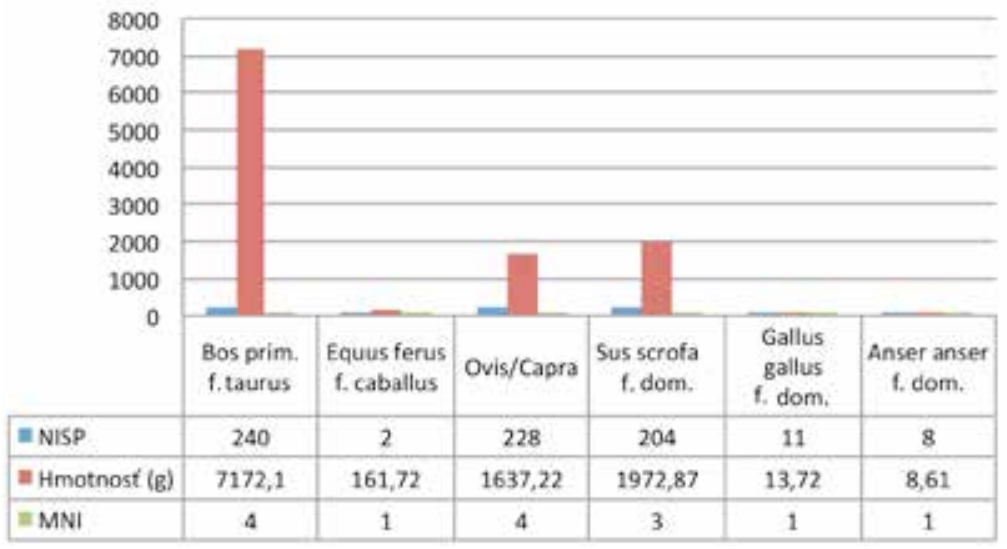

Graf 1. Hrad Dobrá Niva, predhradie. Kvantifikačné zastúpenie domácich druhov.

Diagramm 1. Burg Döbring, Vorburg. Quantifiziertes Vorkommen der Haustierarten.

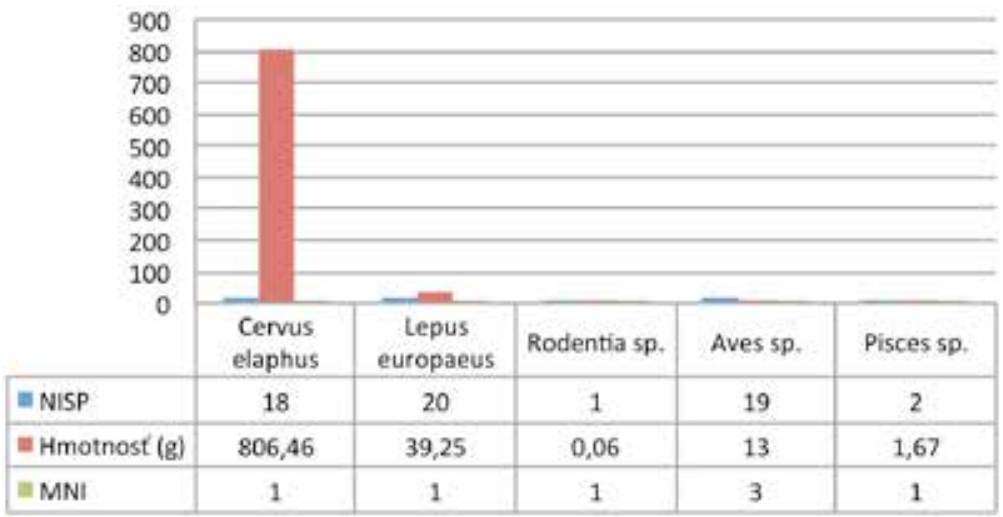

Graf 2. Hrad Dobrá Niva, predhradie. Kvantifikačné zastúpenie divých druhov.

Diagramm 2. Burg Döbring, Vorburg. Quantifiziertes Vorkommen der Wildtierarten.

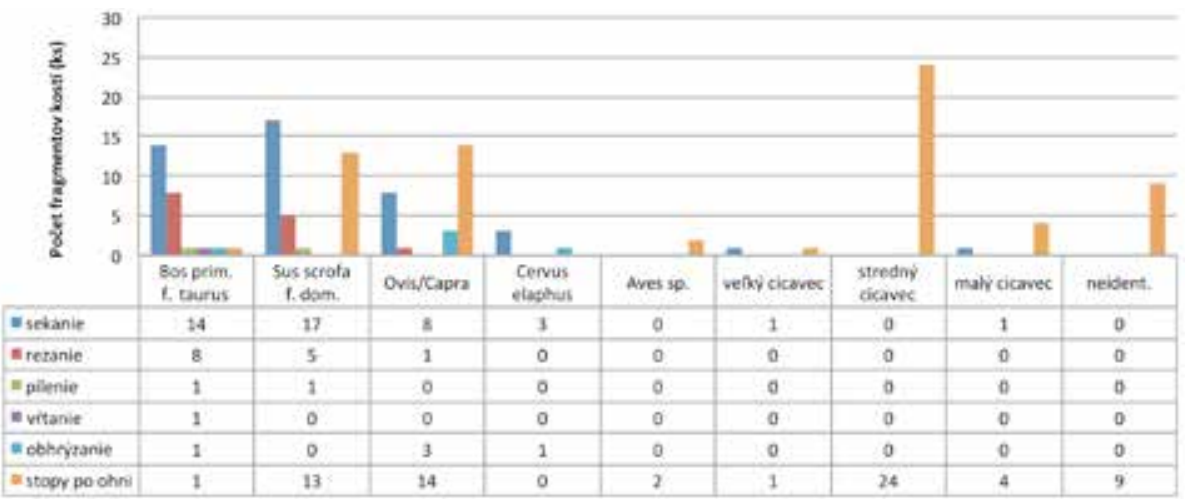

Graf 3. Hrad Dobrá Niva, predhradie. Zásahy na zvieracích kostiach.

Diagramm 3. Burg Döbring, Vorburg. Eingriffe an den Tierknochen. 

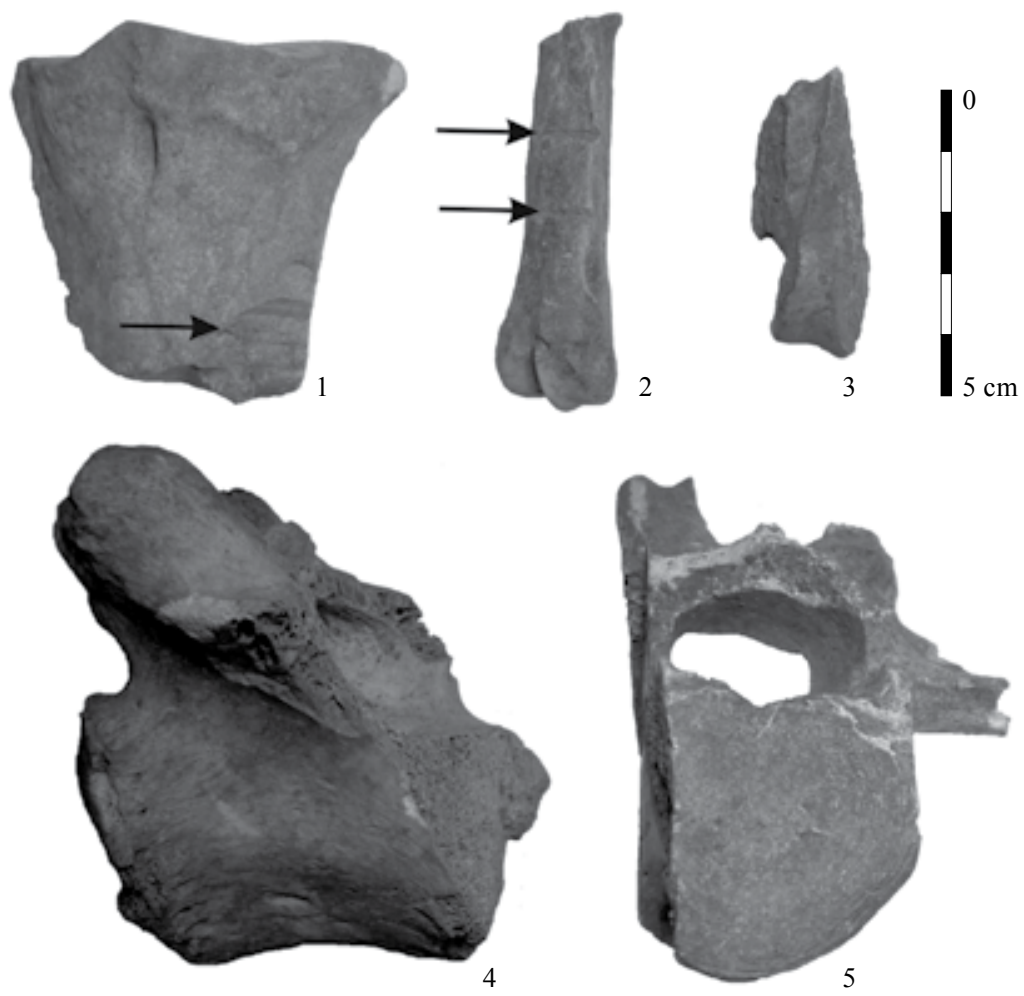

Obr. 3. Hrad Dobrá Niva, predhradie. Stopy po sekaní a rezaní na vybraných zvieracích kostiach. Foto K. Šimunková Abb. 3. Burg Döbring, Vorburg. Schnitt- und Hackspuren an ausgewählten Tierknochen. Foto K. Šimunková

z panvy kozy/ovce a z distálnej časti diafýzy stehennej kosti ošípanej, ktorá navyše niesla na sebe aj znaky po leštení. Jeden fragment z metapódia hovädzieho dobytka vykazoval aj stopy po vítaní.

V niektorých prípadoch (na kosti hovädzieho dobytka, oviec/kôz a jeleňa) boli zaznamenané stopy po obhrýzaní pravdepodobne hlodavcami. Mohlo by to naznačovat' vyhodenie ešte relatívne čerstvej kosti, ku ktorej sa následne dostali tieto komenzálne zvieratá.

O využití zvierat v kuchyni nám svedčia aj stopy po pôsobení žiaru. Tie boli zistené na základe sfarbenia kostného tkaniva na 70 (4,2\%) fragmentoch kostí (graf 4). Sfarbenie do červena, hneda až hnedočierna v prípade 49 fragmentov poukazuje na teplotu $285-525{ }^{\circ} \mathrm{C}$. Do čierna až čiernošeda bolo spálených 11 fragmentov. Tieto zafarbenia kostného tkaniva sa vyskytujú pri teplotách od 525 až do $645{ }^{\circ} \mathrm{C}$. Ďalších desat' fragmentov kostí bolo prepálených do šedobiela a biela, čo naznačuje teploty od 645 do $940^{\circ} \mathrm{C}$ (Shipman-Foster-Schoeninger 1984; Thurzo-Beňuš 2005, 55-56). Išlo predovšetkým o dlhé kosti a rebrá, v menšom počte sa našli stopy po ohni na stavcoch, panve či lopatke alebo článkoch prstov. Vzhl'adom na ich výraznú fragmentáciu môžeme predpokladat', že tieto kosti mohli byt' spal'ované následne ako odpad bud' na otvorenom ohni, ktorý môže dosiahnut' teplotu $380-550{ }^{\circ} \mathrm{C}$, alebo v jamách a v peciach, kde teplota dosahovala od 600 po $900{ }^{\circ} \mathrm{C}$ (Shipman-Foster-Schoeninger 1984; Thurzo-Beňuš 2005, 55-56). 


\section{Vyhodnotenie súboru a porovnanie s analogickými lokalitami}

Vyhodnotený archeozoologický materiál z hradu Dobrá Niva je reprezentovaný hlavne kuchynským odpadom. Dokazujú to stopy po rozličných zásahoch vzniknutých pri porciovaní a spracovaní mäsa, ako aj stopy po tepelnej úprave.

Archeozoologická analýza osvetlila tri hlavné zdroje mäsitej zložky potravy obyvatel'ov hradu. Podl'a lokálnej ekonomiky ich vieme rozdelit' na nasledujúce skupiny.

a) Chov domácich zvierat, ktorý je reprezentovaný $41,7 \%$ kostí z predhradia. Vo väčšom počte bol zastúpený hlavne hovädzí dobytok a ovca/koza, menej ošípaná, kôň a hydina. Zdá sa teda, že mäsitá potrava obyvatel'ov hradu pochádzala najmä $\mathrm{z}$ dobytka. Hlavne v prípade dospelých jedincov to nie je prekvapujúce, nakol'ko podiel využitel'ného mäsa je u nich až $150 \mathrm{~kg}$ (Vörös 2000, 98), na rozdiel od ošípanej, kde v prípade (takmer) dospelého jedinca (adultus/ subadultus) sa podiel spotrebného mäsa pohybuje okolo $40-50 \mathrm{~kg}$ a u mlád’at (juvenilis) len na úrovni $15 \mathrm{~kg}$. Práve v prípade identifikovaných ošípaných v súbore z predhradia išlo výlučne o mladé jedince (medzi 16-24 mesiacom života). Rovnako nie je prekvapujúce, že práve na kostiach hovädzieho dobytka a ošípanej je najviac stôp po sekaní a rezaní, čo vypovedá o ich porciovaní. Žial' archeozoologické údaje nepodávajú informáciu o tom, či sa zvieratá porciovali priamo na hrade, alebo na panstve v okolí. Podl'a urbára Dobronivského panstva, vyhotovenom Esterháziovcami v roku 1652, stáli pod Dobronivským hradom dva majere, v ktorých sa nachádzali dojné kravy, asi 77 kusov záprahového dobytka, približne 260 oviec, 18 svín a 19 úl’ov včiel (Maliniak 2014a, 62).

b) Lov divej zveri, ktorý v súbore zastupovalo 60 kusov kostí. Takýto malý počet nie je ničím výnimočný a odráža skôr dobový trend, nakol'ko pol'ovačka tradične patrila k výsadám

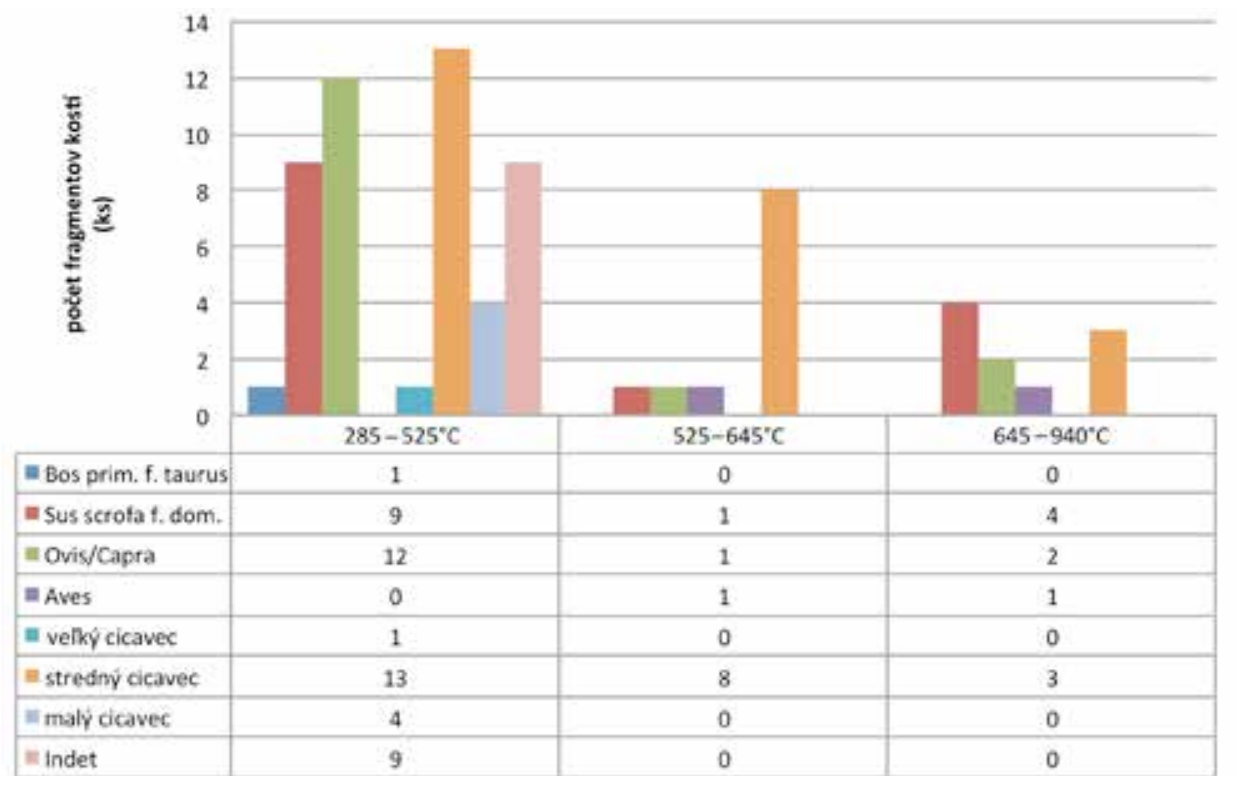

Graf 4. Hrad Dobrá Niva, predhradie. Hodnoty rozsahu pôsobenia teplôt na kosti jednotlivých druhov zvierat.

Diagramm 4. Burg Döbring, Vorburg. Werte des Ausmaßes von Hitzeeinwirkungen auf die Knochen der einzelnen Tierarten. 
zemepánov (Maliniak 2014a, 63). V súbore boli identifikované minimálne tri druhy lovených zvierat: jeleň, zajac a vtáky, pričom sa stopy po sekaní objavili len na kostiach jeleňa. Z paleoekologického hl'adiska môžeme predpokladat', že na lov boli využívané hlavne okolité lesy, vody a pasienky. Napríklad už v závere 15. storočia sa v prameňoch objavujú st’ažnosti z Vígl'ašského panstva na zvolenských a dobronivských kastelánov, ktorí bezuzdne pol'ovali v súkromných zakázaných lesoch (silvas prohibitas) a rybárčili v zakázaných vodách na vígl’ašskom území (Maliniak 2009, 186). Z prameňov sa ale nedozvedáme, či zver bola na panstvá dovezená už naporciovaná a upravená na konzumáciu alebo bola odchytená živá. Zo 17. storočia sú k dispozícii aj historické zmienky o tom, že divá zver bola chovaná v zajatí, prípadne, že zo Zvolenskej stolice boli divé druhy odchytávané a posielané napríklad do zverinca v Smoleniciach (Maliniak 2015, 398-408). Pramene sa zmieňujú aj o vtáčnictve, t. j. lapaní vtákov, avšak nie je konkretizované, či išlo o vtáky na konzumáciu alebo chov. V mestských účtoch zo Zvolena sa v 16. storočí spomínajú hlavne jarabice (Maliniak 2009, 187). Tie boli spolu s divinou oblúbeným doplnkom potravy v prostredí šlachty i meštanov (Duchoňová-Lengyelová 2016, 202), ako aj pri pohostení významnejších hostí.

c) Rybolov, ktorý je často podhodnotený v archeozoologických štúdiách, pretože len vel’mi zriedkavo sa bez preplavovania podarí získat' väčší súbor kostí, prípadne šupín. Aj v našom prípade tento zdroj obživy reprezentujú len dve kosti (artikulárna kost' a čast' čel'uste), pričom konkrétny druh rýb sa nepodarilo identifikovat'. Odchytávané mohli byt' priamo v blízkych riekach a potokoch, nakol'ko poloha hradu Dobrá Niva sa nachádza práve v oblasti s viacerými meandrami a mŕtvymi ramenami. Medzi najznámejšie, ktoré tečú tesne v blízkosti hradu zo západnej strany, patrí potok Neresnica, ktorý je aj v súčasnosti lovným revírom pstruha lososového (Salmo trutta; Kuklová 2014, 19). Zároveň nemožno vylúčit' ani možnost', že v okolí hradu sa nachádzal aj rybník. Dokonca v už spomenutom urbári z roku 1652 sa spomína, že pri mlyne pod hradom bol rybník (Maliniak 2014a, 62).

Nemáme $\mathrm{k}$ dispozícii vel’a porovnatel’ných súborov z hradov z územia Slovenska. Hoci zrejme na všetkých sa vo vel'kom počte objavujú okrem črepov, kachlíc a kovových nálezov aj zvieracie kosti, len v ojedinelých prípadoch sú spracované, resp. publikované. Z obdobia 15.17. storočia máme k dispozícii analýzu z hradu Lietava (Bielich 2015; Vozák 2014) a z Oponického hradu (Repka-Sater-Šimunková 2017, v tlači). Ešte pred porovnaním však okrem odlišného prostredia a zázemia hradov treba upozornit' aj na metodické (v prípade hradu Lietava nie je určený počet fragmentov, s ktorými sa pracovalo; odlišná metodika výskumu vrátane rozloženia skúmaných sond v areáli) i kvantitatívne rozdiely (z Oponického hradu bolo analyzovaných 296 kusov kostí, čo je až osemnásobne nižšie číslo ako z hradu Dobrá Niva) pri spracovaní súborov. $\mathrm{K}$ výsledkom porovnania súborov $\mathrm{z}$ týchto hradov treba preto pristupovat' racionálne a kriticky zhodnotit' výpovednú hodnotu ilustračného porovnávania dobovej fauny.

V pomere domácich zvierat k loveným boli Lietavský hrad a Oponický hrad na relatívne rovnakej úrovni. V obidvoch výrazne prevažovalo zastúpenie domácich druhov ( $97 \%$ a 96,5\%). Na hrade Dobrá Niva je tento stav o niečo nižší (92\%). Skladba domácich zvierat bola rovnaká. Išlo hlavne o hovädzí dobytok, kozy/ovce a ošípané. Podstatne sa však líšili v zastúpení jednotlivých druhov. Najvýraznejší rozdiel je u hovädzieho dobytka. Na Dobrej Nive tvorili fragmenty $32 \%$, na Oponickom hrade $44 \%$ a na Lietavskom hrade len $10 \%$. Rozdiely sledujeme aj u ošípanej, ktorá v súbore z Dobrej Nivy tvorí $27 \%$, na Oponickom hrade $19 \%$ a na Lietavskom hrade len $10 \%$. Najmarkantnejší rozdiel je ale u hydiny, ktorú na Lietavskom hrade zastupuje až $47 \%$ všetkých kostí, kým na Oponickom hrade a na hrade Dobrá Niva tvoria len 3-4\%. V tomto prípade by však bol potrebný aj údaj o počte fragmentov spracovanej vzorky z Lietavského hradu, nakol'ko nevieme určit' mieru skreslenia percentuálneho vyjadrenia vzorky. Rozdiel je pravdepodobne spôsobený metodikou vyhodnocovania výsledkov, a nie tým, že by sa vtedajší obyvatelia Lietavského hradu natol'ko odlišovali od svojich dobových kolegov na ostatných hradoch.

Čo sa týka lovnej zveri, na Dobrej Nive tak ako aj na Oponickom hrade prevažuje vysoká zver, hoci v našom súbore sa vyskytoval ešte aj zajac a divé druhy vtákov. Kosti zajaca boli prítomné aj na Lietavskom hrade, kde bol zachytený spolu s medved’om a líškou hrdzavou (Vozák 
2014,102). A rovnako ako na Lietavskom hrade, tak aj na hrade Dobrá Niva boli zachytené kosti rýb, ktoré dokladajú aj rybolov.

\section{Záver}

Plocha, z ktorej bol materiál z predhradia hradu Dobrá Niva analyzovaný, je pomerne malá, všetky interpretácie sú preto predbežné a po získaní nových nálezov v budúcnosti budú môct' byt' doplnené a korigované. Zatial' presne nevieme, aké rôzne aktivity spracovania mäsitej potravy boli realizované a v ktorej časti hradného areálu sa odohrávali, t. j. do akej miery boli zvieratá na hrade chované, prípadne zabíjané, resp. ako boli organizované rozličné dielne spracovávajúce následne kožu a kosti zvierat. Napriek týmto „negatívam“ analyzovaný súbor vykazuje zaujímavé charakteristiky. Podla dostupných údajov prevláda na väčšine neskorostredovekých a včasnonovovekých hradoch v potrave človeka hovädzí dobytok, nasledovaný ošípanou a ovcou/kozou. Hydina tvorí spravidla menej ako $5 \%$ objavených kostí. Lov bol pre obyvatel'ov predhradia a azda i samotného hradu pravdepodobne len okrajovou záležitostou. Kosti zvierat boli spracované kuchynským spôsobom, pričom do stravy patrilo hlavne mäso z vybraných mäsitých častí tiel zvierat. Zaujímavé je, že analyzovaný súbor nepochádzal priamo z identifikovaného uzavretého objektu, ale išlo o „vol'nú“ plochu a vrstvy vo východnej časti nádvoria. Samozrejme, až budúci výskum osvetlí širšie nálezové súvislosti a istotne doplní aj naše terajšie poznatky o využití zvierat na hradoch.

Príspevok vznikol v rámci riešenia projektu Vedeckej grantovej agentúry Ministerstva školstva, vedy, výskumu a športu Slovenskej republiky a Slovenskej akadémie vied (VEGA) číslo 1/0208/15 Človek a hory $\mathrm{v}$ priebehu času - od pravekých hradísk k stredovekým hradom.

\section{Literatúra}

ADAMS, B. J.-CRABTREE, P. J., 2008: Comparative Skeletal Anatomy. A Photographic Atlas for Medical Examiners, Coroners, Forensic Anthropologists, and Archaeologists. Totowa.

BELJAK PAŽINOVÁ, N.-BELJAK, J.-ŠIMKOVIC, M., 2015: Výskum hradu Dobrá Niva v rokoch 2013 a 2014 - Die Grabungen auf Burg Döbring (Dobrá Niva) in den Jahren 2013 und 2014, AH 40, 583-595.

BIELICH, M., 2015: Archeologický výskum Lietavského hradu v rokoch 2012-2013: piata a šiesta výskumná sezóna - Die archäologische Grabung auf der Burg Lietava in den Jahren 2012-2013: fünfte und sechste Grabungssaison, AH 40, 115-129.

BOESSNECK, J., 1969: Osteological differences between sheep (Ovis aries Linné) and goat (Capra hircus Linné). In: Science in Archaeology: A comprehensive survey of Progress and Research (Brothwell, D. R.-Higgs, E. D., edd.), 311-358. London.

VAN DEN DRIESCH, A., 1976: Das Vermessen von Tierknochen aus Vor- und Frühgeschichtlichen Siedlungen. München.

DRIESCH, A.-BOESSNECK, J., 1974: Kritische Anmerkungen zur Widerristhöhenberechnung aus Langenmassen vor- und frühgeschichflicher Tierknochen, Saugetierkundliche Mitteilungen 22, 325-348.

DUCHOŇOVÁ, D.-LENGYELOVÁ, T., 2016: Hradné kuchyne a šlachtické stravovanie v ranom novoveku. Radosti slávností, strasti každodennosti. Bratislava.

FRANCE, S. L., 2009: Human and Nonhumane Bone Identification. A color atlas. Boca Raton.

GRANT, A., 1982: The use of tooth wear as a guide to the age of domestic ungulates. In: Ageing and sexing animal bones from archaeological sites (Wilson, B.-Grigson, C.-Payne, S., edd.), 91-108. Oxford.

GRAYSON, D. K., 1984: Quantitative Zooarchaelogy. Studies in archaeological science. London.

HAELSTEAD, P.-COLLINS, P., 1995: Sheffield animal bone tutorial: Taxonomic identification of the principal limb bones of common European farmyard animals and deer: a multimedia tutorial. Glasgow.

- 2002: Sorting the sheep from goats: Morphological distinctions between the mandibles and mandibular teeth of adult Ovis and Capra, Journal od Archaeological Science 29, 545-553. DOI: https://doi.org/10.1006/ jasc. 2001.0777

HILLSON, S., 2005: Teeth. Cambridge. 
KLEIN, R. G.-CRUZ-URIBE, K., 1984: The analysis of Animal Bones from Archeological Sites. Prehistoric Archaeology and Ecology Series. Chicago.

KOLDA, J., 1951: Osteologický atlas. Praha.

KUKLOVÁ, M., 2014: Hydrogeologické pomery. In: Dobrá Niva. Monografia obce (Očenášová-Štrbová, S., ed.), 17-19. Dobrá Niva.

KYSELÝ, R., 2004: Kvantifikační metody v archeozoologii - Quantification methods in archaeozoology, AR LVI, 279-296.

LYMAN, R. L., 2008: Quantitative Paleozoology. Cambridge.

MALINIAK, P., 2009: Človek a krajina Zvolenskej kotliny v stredoveku. Banská Bystrica.

- 2014: Stredoveké mestečko a jeho obyvatelia. In: Dobrá Niva. Monografia obce (Očenášová-Štrbová, S., ed.), 53-58. Dobrá Niva.

- 2014a: Z histórie v ranom novoveku. In: Dobrá Niva. Monografia obce (Očenášová-Štrbová, S., ed.), 59-66. Dobrá Niva.

- 2015: Úlovky, dary a jelene v maštali. Sociálne a kultúrne pozadie pol’ovníctva vo Zvolenskej stolici. In: Človek a svet zvierat v stredoveku (Dvořáková, D. a kol.), 393-408. Bratislava.

O'CONNOR, T., 2000: The archaeology of animal bones. London.

PAYNE, S., 1973: Kill-off patterns in sheep and goats: the mandibles from Asvan Kale, Anatolian Studies 23, 281-303.

- 1987: Reference codes from wear states in the mandibular cheek teeth of sheep and goats, Journal of archaeological Science 14, 609-614. DOI: https://doi.org/10.1016/0305-4403(87)90079-3

POPESKO, P., 2007: Atlas topografickej anatómie hospodárskych zvierat. I.-III. diel. Bratislava.

REITZ, E. J.-WING, E. S., 2008: Zooarchaeology. Cambridge.

REPKA, D.-SATER, P.-ŠIMUNKOVÁ, K., v tlači: Archeologické nálezy z Oponického hradu, ŠZ AÚ SAV 2017.

SHIPMAN, P.-FOSTER, G.-SCHOENINGER, M., 1984: Burnt bones and teeth: an experimental study of color, morphology, crystal structure and shrinkage, Journal of archaeological science 11, 307-325.

SCHMIDT, E., 1972: Atlas of Animal Bones. For Prehistorians, Archaeologists and Quaternary Geologist. Amsterdam - London - New York.

TEICHERT, M., 1969: Osteometrische Untesuchungen zur Berechnung der Widerristhöhe bei vor- und frühgeschichtlichen Schweinen, Kühn-Archiv 83, 237-292.

THURZO, M.-BEŇUŠ, R., 2005: Základy tafonómie hominidov a iných stavovcov. Bratislava.

VOZÁK, Z., 2014: Archeozoologická analýza nálezov z Lietavského hradu z rokov 2008-2010. In: Hrad Lietava 2003-2013, 10-103. Lietava.

VÖRÖS, I., 2000: Adatok az Árpád-kori állattartás történetéhez. In: A középkori magyar agrárium (Bende, L.-Lörinczy, G., edd.), 71-119. Ópusztaszer.

\section{Zusammenfassung}

\section{Der Fleischkonsum in der Neuzeit auf Burgen: Eine Fallstudie von Burg Döbring}

Das Nationale Kulturdenkmal Burg Döbring liegt auf einer konischen Erhebung (Abb. 1) in einer Entfernung von $3 \mathrm{~km}$ nördlich der eponymem Gemeinde in der Mittelslowakei im Kreis Zvolen. Das Burgareal hat eine zweiteilige Disposition von ovalem Grundriss und Abmessungen von ca. $80 \times 90 \mathrm{~m}$ (Abb. 2). Die dort vom Lehrstuhl für Archäologie der Universität Konstantin der Philosoph in Nitra durchgeführten archäologischen Grabungen erfolgten im Jahr 2013 (in Zusammenarbeit mit dem Archäologischen Institut der Slowakischen Akademie der Wissenschaften in Nitra) und im Jahr 2014 (Beljak Pažinová-Beljak-Šimkovic 2015).

Alle in dem vorliegenden Beitrag analysierten Knochen stammen aus Sondierungsgrabungen, die im östlichen Teil der Vorburg durchgeführt wurden. Die Funde wurden in einer Schicht entdeckt, die in die Zeit zwischen dem 15. und 17. Jahrhundert datierte Keramik und Kacheln enthielt. Insgesamt handelte es sich dabei um 1660 Knochenfragmente $(14,8 \mathrm{~kg})$. Der Gruppe unbestimmbare Arten (Indet.), bzw. der Gruppe große, mittlere und kleine Säugetiere wurden 907 Exemplare zugeordnet (54,6\%).

Die anatomische und taxonomische Bestimmung der Knochen erfolgte auf Grundlage der verfügbaren Veröffentlichungen von Tierärzten, Anatomen und Archäozoologen unter 
Heranziehung eigener Vergleichssammlungen. In die Analyse wurden gleichzeitig auch die Quantifizierungsmethoden NISP und MNI aufgenommen.

Durch die Analyse des osteologischen Materials konnte eine große Vielfalt an Tierarten festgestellt werden. In dem Fundkomplex dominierten Haustierarten: Hausrind (Bos primigenius f. taurus), Hausschwein (Sus scrofa f. dom.), Ziege (Capra aegagrus $f$. hircus), Schaf (Ovis aries f. aries), Pferd (Equus ferus f. caballus), Gruppe Schaf / Ziege (Ovis/Capra), mit geringem Anteil an Geflügel - Haushuhn (Gallus gallus f. dom.) und Hausgans (Anser anser f. dom.).

An Wildtieren (Diagramm 2) waren in den Proben folgende Arten vertreten: Rothirsch (Cervus elaphus) und Feldhase (Lepus europaeus). Es kamen auch Wildvogelarten (Aves sp. indet.), Fische (Pisces sp. indet.) sowie ein Knochen eines nicht näher bestimmten Nagetiers vor.

Die an 64 Exemplaren (3,8\%) festgestellten Eingriffsspuren (Abb. 3; Diagramm 3) deuteten darauf hin, dass die Knochen geschnitten, zerhackt und sogar auch zersägt wurden, wodurch bestätigt wird, dass sie hauptsächlich zu Küchenzwecken verwendet wurden. Spuren einer Hitzeeinwirkung zeigten sich bei 70 Exemplaren (4,2\%; Diagramm 4).

Durch die Analyse konnten drei Hauptquellen an Fleischkomponenten in der Ernährung der Burgbewohner ausgemacht werden:

a) Haustierhaltung (41,7\% der Knochen). In größerer Anzahl waren vor allem Hausrinder und Schafe/Ziegen vertreten, weniger dann Schweine, Pferde und Geflügel. Laut dem Urbar der Grundherrschaft Döbring aus dem Jahr 1652 standen unterhalb der Burg zwei Bauernhöfe, in denen sich Milchkühe, anscheinend 77 Tiere Zugvieh, annähernd 260 Schafe, 18 Schweine und 19 Bienenstöcke befanden (Maliniak 2014a, 62).

b) Wildtierjagd (60 Knochenexemplare). Eine solch geringe Anzahl ist nichts außergewöhnliches und spiegelt eher den Trend der Zeit wider, da die Hälfte traditionell zu den Vorrechten der Landesherren gehörte (Maliniak 2014a, 63).

c) Fischfang (nur zwei Gräten, ohne durchzuspülen entdeckt). Fische konnten direkt in den nahegelegenen Flüssen und Bächen gefangen werden. Im Urbar aus dem Jahr 1652 wird sogar erwähnt, dass sich an der Mühle unterhalb der Burg ein Fischteich befand (Maliniak 2014a, 62).

Aus der Zeit des 15.-17. Jahrhunderts stehen uns die Kollektionen von Burg Lietava (Bielich 2015; Vozák 2014) und von Burg Apponitz (Repka-Sater-Šimunková 2017, im Druck) als Vergleichsmaterial zur Verfügung. Es scheint, dass auf den meisten hochmittelalterlichen und frühneuzeitlichen Burgen in der Ernährung der Menschen Rindfleisch überwog, gefolgt von Schweinefleisch und Schafs-/Ziegenfleisch. Geflügel macht in der Regel weniger als $5 \%$ der entdeckten Knochen aus. Bei der Jagd könnte es sich eher nur um eine marginale Angelegenheit gehandelt haben.

Der vorliegende Beitrag entstand im Rahmen des Förderprojekts der Wissenschaftlichen Förderagentur des Ministeriums für Schulwesen, Wissenschaft, Forschung und Sport der Slowakischen Republik und der Slowakischen Akademie der Wissenschaften (VEGA) Nr. 1/0208/15 Der Mensch und die Berge im Laufe der Zeit - von urzeitlichen Burgwällen bis zu mittelalterlichen Burgen.

Mgr. Katarína Šimunková, Katedra archeológie Filozofickej fakulty Univerzity Konštantína Filozofa v Nitre, Hodžova 1, SK 94901 Nitra, Slovenská republika, katarina.simunkova@gmail.com

doc. PhDr. Noémi Beljak Pažinová, PhD., Katedra archeológie Filozofickej fakulty Univerzity Konštantína Filozofa v Nitre, Hodžova 1, SK 94901 Nitra, Slovenská republika,nbpazinova@ukf.sk 
